\title{
The Cartesian Split
}

The Cartesian Split examines the phenomenon of Cartesian influence as a psychological complex in the Jungian tradition. It explores the full legacy of Cartesian rationality in its emphasis on abstract thinking and masculinisation of thought, often perceived in a negative light, despite the developments of modernity.

The book argues that the Cartesian creation of the Modern Age, as accompanied by a radical dualism, is better understood as a myth while acknowledging the psychological reality of the myth. The Cartesian myth is a collective dream, and the urgency of its rhetoric suggests that an important message is being left unheeded. This message may lead us to answers in the most unexpected place of all. The book brings forth the Cartesian myth in a new context and shows it to have potential meaning for us today.

The book will be of great interest for academics, researchers, and post-graduate students in the fields of analytical psychology, mental health, comparative mythology, and Jungian studies.

Brandon D. Short is a mechanical engineer with an interest in psychology. He holds a doctorate of depth psychology from Pacifica Graduate Institute. He lives in Portland, Oregon, USA. 
Research in Analytical Psychology and Jungian

Studies Series

Series Advisor: Andrew Samuels, Professor of Analytical Psychology, Essex University, UK.

The Research in Analytical Psychology and Jungian Studies series features research-focused volumes involving qualitative and quantitative research, historical/archival research, theoretical developments, heuristic research, grounded theory, narrative approaches, collaborative research, practitioner-led research, and self-study. The series also includes focused works by clinical practitioners, and provides new research informed explorations of the work of C. G Jung that will appeal to researchers, academics, and scholars alike.

Books in this series:

Jungian Metaphor in Modernist Literature Exploring Individuation, Alchemy and Symbolism Roula-Maria Dib

\section{Symbolic Mental Representations in Arts and Mystical Experiences \\ Primordial Mental Activity and Archetypal Constellations \\ Giselle Manica}

Jung's Technique of Active Imagination and Desoille's

Directed Waking Dream Method

Bridging the Divide

Laner Cassar

The Cartesian Split

A Hidden Myth

Brandon D. Short

For more information about this series please visit: https://www.routledge. com/Research-in-Analytical-Psychology-and-Jungian-Studies/book-series/ JUNGIANSTUDIES. 


\title{
The Cartesian Split
}

\author{
A Hidden Myth
}

\section{Brandon D. Short}

\author{
올 Routledge \\ 尊 Taylor \& Francis Group


First published 2021

by Routledge

2 Park Square, Milton Park, Abingdon, Oxon OXI4 4RN

and by Routledge

52 Vanderbilt Avenue, New York, NY 10017

Routledge is an imprint of the Taylor \& Francis Group, an informa business

(C) 202I Brandon D. Short

The right of Brandon D. Short to be identified as author of this work has been asserted by him in accordance with sections 77 and 78 of the Copyright, Designs and Patents Act 1988.

All rights reserved. No part of this book may be reprinted or reproduced or utilised in any form or by any electronic, mechanical, or other means, now known or hereafter invented, including photocopying and recording, or in any information storage or retrieval system, without permission in writing from the publishers.

Trademark notice: Product or corporate names may be trademarks or registered trademarks, and are used only for identification and explanation without intent to infringe.

British Library Cataloguing-in-Publication Data

A catalogue record for this book is available from the British Library

Library of Congress Cataloging-in-Publication Data

A catalog record has been requested for this book

ISBN: 978-0-367-24593-I (hbk)

ISBN: 978-0-429-28335-2 (ebk)

Typeset in Sabon

by codeMantra 


\section{To Cassandra}



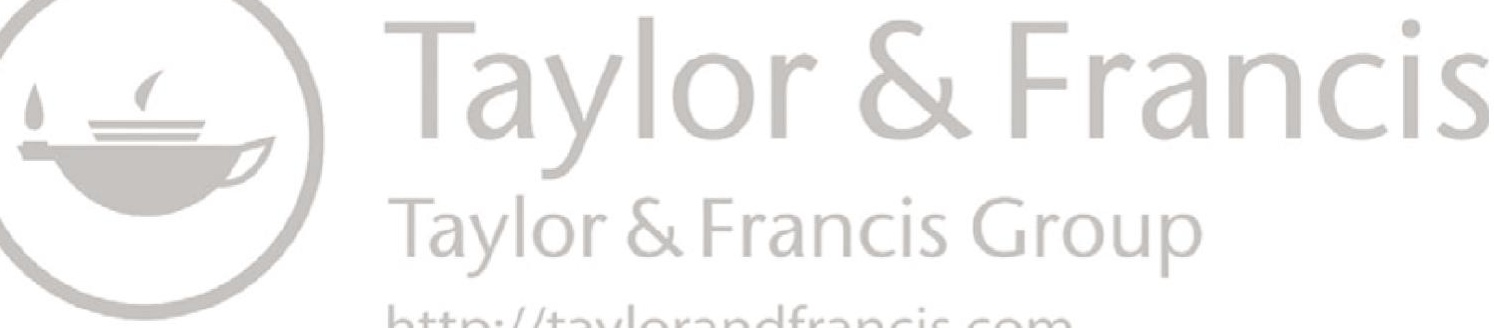

http://taylorandfrancis.com 


\section{Contents}

List of figures $\quad$ xi

Preface xiii

Epigraph xvii

1 Introduction 1

The allure of the error 1

The split in the middle 4

Approaching the split 6

The complexity of complexes 9

Cogito ergo non sum 11

A complex offering 13

Outline of chapters 14

2 The initial sessions

Body as machine 19

Ecological crisis 21

Feminist challenge 22

Subjective difficulties 23

Over-rationality 25

Limitations in expression 25

Reduction and isolation 27

Pairs of opposites 28

The dominant paradigm 30

Old versus new 32

Heroic transcenders 33

Tragic transcenders 36

Charged images 40

First evaluation 41 
3 The depth sessions

The great revolt 50

The ghost in the machine 52

The masculinization of thought 54

Cartesian disenchantment 56

The Cartesian mirror 58

The Cartesian theater 58

The turning point 60

The murder of the world soul 65

Further evaluation 67

4 Confronting the legend

The dawn of awareness 71

The problem of interpretation 72

The problem of caricature 74

The reality of the problem 77

Descartes' dualism 79

The legend 80

The two worlds view 81

Critiquing the legend 84

Finding truth in myth 86

5 Ancient memories

Tales of the mirrored world 91

The first mirror 95

The dark mirror 97

The original split 100

The Gnostic two worlds 101

The chief archon 105

The splitting of the demiurge 111

A terrible world order 112

The first machine 115

Feminism and ecology 117

Solipsism and materialism 118

Gnostic transcenders 122

Summary 123

6 Psychological interpretation

Interpretation of the mirrored worlds 126

Becoming conscious of consciousness 127

Differentiation of opposites 128 
Crossing the threshold 129

Mutual causation 130

The one world of certainty 131

The creation of consciousness 132

Death at the threshold 133

Interpretation of the split worlds 135

Gnostic consciousness 137

Atomic consciousness 139

Inside the split 140

The splitting of the ego 143

The splitting of consciousness 145

Modern dismemberment 148

7 Cultural memories

The Anglo-split 153

Anamnesis 155

A new look at olde times 155

Dismemberment on stage 157

The sudden shift 158

The splitting of ritual 160

The splitting of the play 162

The splitting of cultural consciousness 164

Faustus's internal split 166

The residual memory 168

A penny for the Guy 168

Religious dualism 170

The splitting of substance 171

Substantial epochs 173

8 The alien text

Descartes' disclaimer 180

The evil genius 181

Cogito and consciousness 182

Meditations on split consciousness 185

Internalizing doubt 187

The process of doubt 188

A singular truth 189

A single sapling 191

Inoculation 191

The one small part 194

The religious problem 196

Meditations on God 198 
Divine substance 199

Mysterious substance 200

Altered substance 202

Altered meditations 204

Index 


\section{Figures}

1.1 Author's impression of bookstore drawing 1

2.1 Thematic map of the survey of abstracts 42

$\begin{array}{ll}5.1 \text { Summary of mythic elements } & 91\end{array}$

$\begin{array}{lll}5.2 & \text { Descartes, by Baudran } & 109\end{array}$

$\begin{array}{ll}5.3 \text { Newton, by Kneller } & 110\end{array}$

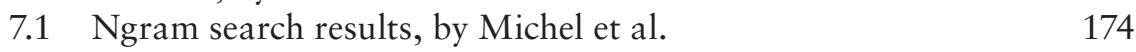



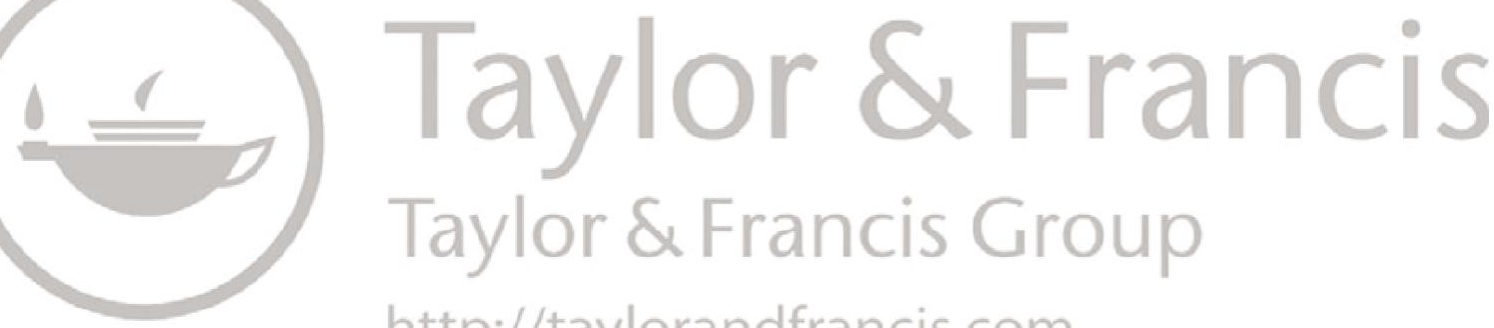

http://taylorandfrancis.com 


\section{Preface}

The Western academy has a father complex. This complex is deep and tumultuous, rife with emotion and resentment, while also compulsive and irrational. For sure, the academy has a long and respectable tradition, venerated and sophisticated, featuring some of the best minds doing some of the best research. But in this one respect, it is like a child that is overly fixated on its father, too obsessed with escaping his long shadow. This father is none other than René Descartes, the 17th-century philosopher now known as the "father of modern philosophy." In a postmodern age, he is the icon of modernity most commonly rejected, oftentimes with glee.

The father complex itself is perhaps best known as one half of the Oedipus complex. This was given to us from another father, Sigmund Freud, the father of psychoanalysis. In Freud's writings, the Oedipus complex looms ominously, present to some degree in nearly every case study. Deep down, says Freud, we all harbor deep resentment and antipathy toward our fathers. This idea is perhaps not so well accepted anymore, but it does offer a useful perspective on our collective attitude toward Descartes. In nearly every academic field, it is common to find an urgent exhortation, in some form or another, for a complete emancipation from Cartesian influence. It is presumed that such influence is widespread, pernicious in its effects, and must be singled out and rejected before any further progress can be made. In other words, this collective child of the Academy feels compelled to kill its father.

Although this complex is multi-faceted, one particular aspect of it is surely the infamous doctrine of Cartesian dualism. Of all the Cartesian ideas to reject, this is the one that seems to be the most urgent. Why? Often, it is assumed that this idea is not just a present problem but marks an unusually tragic event in Western history. It is believed that in previous epochs, the mind, or one's own inner self, was considered to be harmonious and contiguous with all other levels of existence. However, it is said, Descartes drove a stake through the heart of this original wholeness and divided it into two. This was not just substance dualism but a radical dualism. Mind was now separate from body, subject was now separate from object, and 
inner was now separate from outer. The soul itself, once the most privileged mode of existence, suddenly found itself split off and separated from nearly everything else. Contemporary critiques go to great lengths to show that this division into two was invalid and illegitimate. The child must kill the father by healing the split.

Some readers may object to me referring to this behavior as a complex, on several levels. For one, the commonplace usage of the term is usually reserved for individuals and not groups. Another, perhaps larger, objection might be toward the overall sense of validity. Often, the word "complex" is invoked to discredit an opinion, to reduce its claim of objectivity. But surely, such a rejection of dualism is "objectively" true? After all, there is a long line of highly respected figures who have made this critique, as I will show. They cannot all be acting out of some kind of a psychological error. Or can they? I will address these concerns and others throughout the book. For now, it is enough to state that, in spite of all the excellent work by these figures, there is yet something else.

What is missing is a full recognition that these critiques, however well argued, are based on a gross mischaracterization of Descartes' original philosophical arguments. It is not so much a distortion, however, as an additional story, overlaid on top of the historical facts. It is a subliminal, compulsive story, running throughout many such critiques, and has seemingly taken on a life of its own. It is like an internet meme gone viral, such that it has completely transcended its humble origins. Others have noticed this problem, and critiqued it, but it seems to live on, unperturbed. It is in this respect that I consider it to be a complex.

However, I wish to emphasize that I have no intention of denigrating these critiques. On the contrary, I consider them all to be highly valuable, precisely because it is a complex. I am suggesting that this complex is not so much bad philosophy as misunderstood fantasy, a hidden myth, hiding in plain sight. I will contend that it contains within it, at least potentially, a meaningful message. To recognize this, uncover it, and understand it better is the aim of this book.

Notably, this book is a work in psychology, but I do not intend it to be limited to a psychological audience. It is intended for all academic fields that have claimed an intellectual tradition that has been somehow influenced by Descartes. This range is far beyond just philosophy, extending as far as art history and religious studies. For such a wide audience, I will limit the use of specialized terminology specific to psychology. Instead, I intend to liberally employ metaphor and an intentional personifying of the contents of the study. In other words, I will attempt to tell a story, with subjects as much as concepts.

So, imagine if you will, a person named "Ash" who has decided to go into therapy. Ash is having trouble at work and in relationships, specifically with authority figures. Whenever a problem is encountered, in any life situation, 
it always seems to revolve around some leader or historical founder. When asked for more detail, Ash consistently recalls events from early childhood, especially those involving Ash's father, Rand. At these moments of the conversation, emotions are raised, and Ash's face becomes contorted and bitter. The therapist recognizes at once a textbook father complex. Yet the situation is also quite delicate, and so the first task is, crucially, to listen.

In this book, Ash is the Western academy, Rand is Descartes, and I hope to be the therapist. So now, I invite Ash to lie back, relax, and please, "tell me about your Father.” 

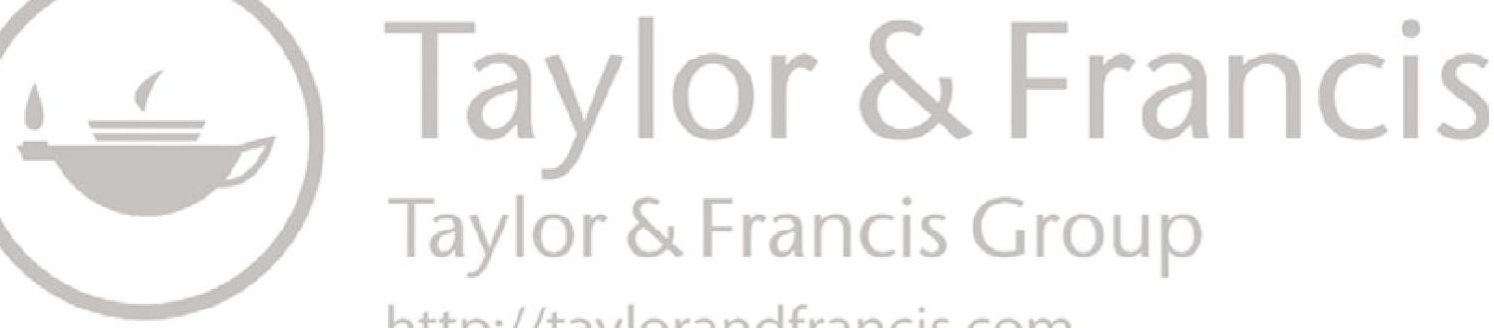

http://taylorandfrancis.com 


\section{Epigraph}

I had this dream, a big dream...

I am walking down the streets of my old neighborhood, until I come to my childhood house. But it was different. In the front yard, there were these two large stone hands coming out of the ground, cold and pale, one on the left and one on the right. Then, the sky darkened, a terrible wind gathered, and I was afraid. A huge Captain Hook figure rose up slowly from behind the house. He let out a maniacal, evil laugh, and a thunderbolt came crashing down, splitting the house into two. I think my mother was still in there. I was terrified, and tried to close my eyes, but something held my gaze. Nothing happened for a very long time. Then, something rises from beneath the rubble, right in the middle. It is a unicorn, untouched and unharmed. It levitates and floats gently in the breeze, staring right at me the whole time. I feel a sense of peace, but I do not know what to do. Then, I woke up. 

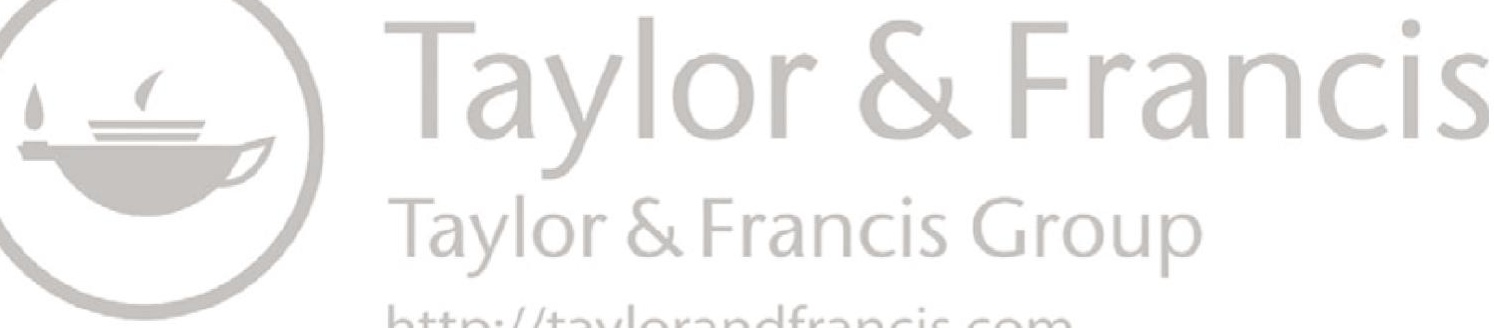

http://taylorandfrancis.com 


\section{Chapter I}

\section{Introduction}

\section{The allure of the error}

I remember the day well. I was strolling the aisles of my favorite bookstore, a very large bookstore, but one that still has a small bookshop feel. Noteworthy books will often get hand-written notes from the staff, placed under the stacks, guiding the shopper with useful commentary. On this day, one such note really caught my eye. It was underneath a popular book on modern neuroscience, titled Descartes' Error, by Antonio Damasio. The book had merited the title of "Staff's Picks," a glowing recommendation. But beyond this, the reviewer felt compelled to spend a little extra time on the note, to add a somewhat comical drawing of Descartes, looking something like this:

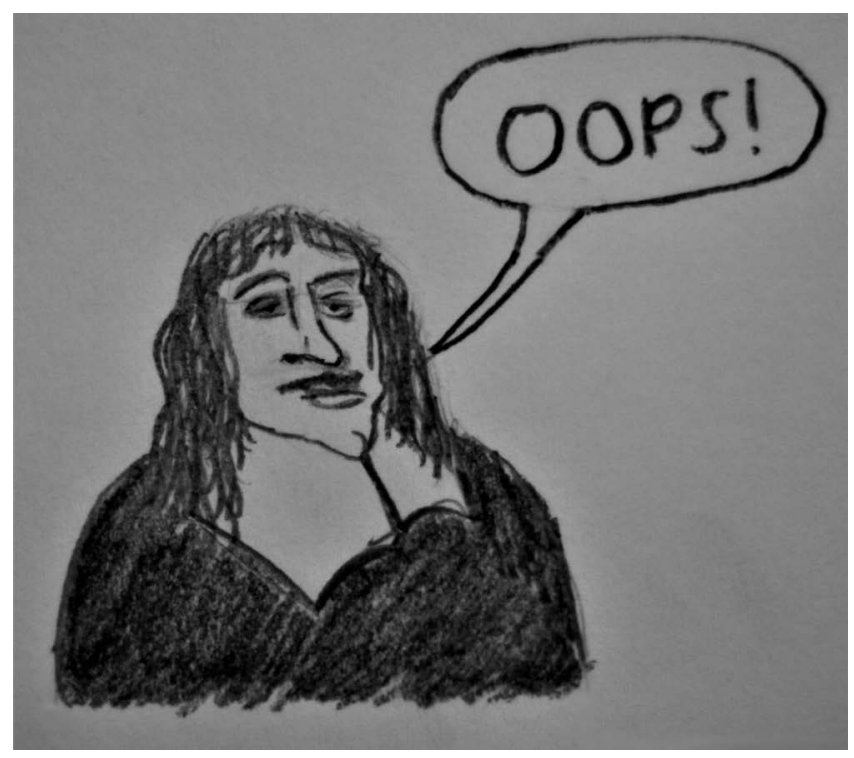

Figure I.I Author's impression of bookstore drawing. 
At the time, the book was already a bestseller, but this hand-drawn image could have probably sold many more all by itself. The "OOPS!" says it all. How very tantalizing! Provocative! A relatively unknown neuroscientist had managed to expose the father of modern philosophy as fraudulent, foolish even. A legendary figure, required reading in every college philosophy class, was forced to humble himself before the miraculous discoveries of modern science, and sheepishly admit he got it all wrong.

Upon opening the book, in the very first pages, similar recommendations are found from professional reviewers. In particular, Damasio is celebrated for triumphantly overcoming the legendary influence of Cartesian thought. One reviewer states, "Damasio boldly challenges the dualisms that have dogged Western thought" (as cited in Damasio, 2006, p. i). In another edition, we learn that Damasio "cogently rejects simplistic divisions." The opportunity presented by this rejection is quite exciting. This "astonishing book. . . reveals the invisible world within us." It is a "revolutionary portrait," which "challenges the dogma." A call is issued to a wide range of scholars: "By all means, read this book" (as cited in Damasio, 1995, pp. i-iii).

The overall message is clear: Cartesian influence is widespread but is now recognized to be seriously flawed. While it may have helped contribute to modern science, with all of its accompanying benefits to humanity, now it is seen to be deeply harmful. Future progress depends on transcending this influence, to find a more holistic, natural, and reasonable conception of the human being. Who could possibly turn away from such a rich and promising proposition? It just feels like the right thing to do.

This basic feeling is at the core of my investigation. I have no interest in critiquing Damasio's neuroscientific findings, which are surely with merit. However, I do wish to investigate this feeling, the general tone of "antiCartesianism," that clearly accompanies the book, both on the cover and on the shelf.

It is fair to ask why a feeling, especially one with such broad acceptance, should become a research subject in its own right. One reason is that, for all its supposed importance, it is surprisingly ephemeral, and difficult to locate precisely. For example, upon opening the book, there is a conspicuous lack of anything related to Descartes. The infamous philosopher does not even show up until the final five pages. Even Damasio (1995) himself acknowledges that the formative stuff of the book "was neither about Descartes nor about philosophy" (p. xix). But for some reason, he felt compelled to name it after him and his egregious error. Why? I suspect it is for the same reason that the bookstore artist felt compelled to draw an amusing caricature of the intended target.

Whether Damasio was aware of it or not, this general tone of antiCartesianism is very popular, and naming the book along these lines probably helped to secure a warm reception to the book, and among a very broad audience. For one particular example of this, the book has been 
enthusiastically endorsed by Daniel Dennett (1995), a philosopher of mind and a prominent voice in modern consciousness studies. Dennett's own view is heavily materialistic, famously stating that consciousness is an illusion, and this is quite harmonious with Damasio's rejection of Descartes' cogito. Meanwhile, in a corner of the academy very far removed from Dennett, there is Coppin and Nelson's (2005) The Art of Inquiry. This small book, focused on qualitative research methodology, also advocates for Damasio, although for a very different reason. Coppin and Nelson are concerned that qualitative research has become too dry and technical, emulating the hard sciences too much, and as such, has lost its soul. Damasio's book is celebrated, because it confirms a holistic conception of the human psyche, "the bodymind," where soul is not separate from body (pp. 154-155). With this view, qualitative research can become more like the arts, more aesthetic and romantic, welcoming the soul back in.

I should not have to state that the audiences of these two books are quite different. Among the audience of the latter book, Dennett's rigorous materialism is usually met with a certain hostility. On the other hand, Dennett would probably not be too moved by the critique that anything scientific has lost its soul. Although there are surely some things in Damasio's book that are agreeable to both audiences, I suspect that the title of the book has significantly increased the chances of a positive evaluation, regardless of the audience and their background. In this case, as it is often the case with Descartes, the enemy of my enemy is my (unacknowledged) friend.

This feeling of anti-Cartesianism is broad, extending into many other fields, and interestingly, it has remarkable staying power. Damasio's "revolutionary" book came out in 1994, became a best-seller, and gained broad approval. It has also reached far beyond academic confines; you can even buy t-shirts online featuring the book's title ("Descartes Error-Mixed Mental Arts-T-Shirt I TeePublic," 2019). Once an idea has reached this kind of mass penetration, it would seem safe to say that the victory has been won. Ostensibly, Cartesian influence should have been eliminated by now, or at least, clearly sequestered.

And yet, the revolution goes on; 24 years after Damasio's book was published, an article appeared in the online Psychology Today, which seems to call for a similar pointed rejection, all over again. In this article, McCann and Bechsgaard (2018) generally recapitulate the overall feeling of Damasio's book, or at least the front cover, as I have summarized above. They call for a wholesale rejection of Cartesian influence, almost as if Damasio's book was never written. The article ends with a nice summation, and a poignant image, and so is worth restating it in whole:

The call for the rejection of this limited view is coming from a variety of quarters.... We urgently need to replace the machine metaphor which has re-shaped how we see both the human body and the human mind. 
We need to break up with Rene Descartes. The letter might go something like this:

Dear Rene,

It has been an eventful 500 years and we have been through a lot together. As exhilarating as it has been it is time for us to go our separate ways.

Sincerely, the Western World (para. 7)

And yet, given the ongoing nature of this rejection, it is perhaps easier said than done. Perhaps we have solemnly realized that we are in an abusive relationship, but we are too far in it to be willing to undergo a difficult break-up. According to a book titled Goodbye, Descartes, we learn that Cartesian influence is so deeply "ingrained in the psyche of twentiethcentury Western man that any theory that challenges that view is bound to have a hard time of it" (Devlin, 1998, p. 279). This, of course, does not dissuade Devlin, and others, from valiantly trying. Perhaps all of these authors are simply doing what they can, chipping away at the old harmful edifice, one brick at a time, taking the long view of faith that one fine day will bring the final emancipation. Regardless, it seems the feeling of antiCartesianism can draw a powerful, long-lasting interest.

\section{The split in the middle}

The scope of my investigation must be focused further. Simply "antiCartesianism," in all its varied forms, is much too broad. For whatever reason, Descartes has always been an unusually big target, from times long before Damasio. He has been "attacked, reviled, and condemned like no other thinker for most of the last 350 years" (Bracken, 2002, p. 1). To make things more difficult, he has also been a moving target. Gaukroger (1998) states, "more than any other modern philosopher, he has been fashioned according to the philosophies of the time and interpreted accordingly" (p. 3). For example, Descartes drew the ire of many of his contemporaries, including both Voltaire and Pascal, but for different reasons from each other, and for very different reasons than we have today. Even if I were to restrict my study to only current sources, I could not possibly account for all the unusually harsh critiques levied at Descartes.

However, there is one modern critique in particular that can be defined and recognized precisely. It is the usual argument against Cartesian dualism, but with much more colorful rhetoric, and strikingly more dramatic claims. It is in fact no longer an argument, but a vehement rejection; no longer a debate in philosophy, but an existential crisis. It is the urgent call to transcend the radical Cartesian Split.

This new target is perhaps exemplified by Walker Percy (1999), in his novel Love in the Ruins. In it, the protagonist feels he has finally realized 
the solution to this age-old problem, as he scribbles feverishly in his notebook:

Hear the triumphant news... the first hope of bridging the dread chasm that has rent the soul of Western man ever since the famous philosopher Descartes ripped body loose from mind and turned the very soul into a ghost that haunts its own house.

As I will show later, there are many variants of this notion, but this image of disastrous and tragic separation, or specifically, a "split," can be seen as a convenient common thread. Perhaps all the other critiques are related to this, but the split serves as a highly useful focal point. For example, Damasio (1995) himself nicely echoes this sentiment when he finally defines Descartes' error as "the abyssal separation between body and mind" [italics added] (p. 249). And so, there is a widespread and urgent interest in overcoming Cartesian influence, and now there is a specific target of that rejection, the legendary Cartesian Split. The split must be transcended, or healed, if we are to go on. Ironically, if we were to go through with the break-up with Descartes, this would amount to healing the split by splitting up.

This irony should give us pause. Before we split up with Descartes, we should first understand what exactly he split up. There are many ways to approach this, but perhaps it is best, again, to begin with the focal point, these images of dread chasms and abysses. To put it simply, such images have very little to do with actual Cartesian philosophy. In spite of these author's good scholarship in other areas, the idea that Descartes argued for such a profound and radical separation, is just that, an idea. This interpretation, if it can be called that, is drastically out of step with most of the dedicated commentary on the subject.

Among philosophers, for example, there is widespread agreement that Descartes argued for a distinction between mind and body, rather than a separation. There is also wide agreement that, in addition to this distinction, he also argued for a rather intimate, two-way causal interaction between body and mind. The usual critique in this community is not so much against dualism per se, but that Descartes failed to convince on the manner of the interaction, or made some fatal logical error, such as the Cartesian circle. Third, the common interpretation of Descartes' "mind," the cogito, is quite different than in most of the above sources. For Damasio, for example, $\operatorname{cog}$ ito means abstract, intellectual thinking, or the kind of thinking opposed to the emotions. Whereas, for most philosophers, cogito includes the emotions.

While even this interpretation is problematic, which I will address later, it is important to note at this point that the notion of a radical split, is simply not found in the source texts. On the contrary, in the 6th meditation, Descartes (1984) details how the mind and body are united. 
To illustrate this, he uses a metaphor of a sailor on a ship, representing mind on a body. This is perhaps a metaphor that could be used by many today. In this metaphor, the mind and body are connected, but it turns out that the manner of connection does not suit Descartes. Interestingly, he argues for an even more intimate union than this would allow. He states, "I am not merely present in my body as a sailor is present in a ship, but that I am very closely joined and, as it were, intermingled with it, so that I and the body form a unit" (p. 56). Further, the activity of such an "I" implies more than just the intellect. Descartes defines "thinking" as the activity of that which "doubts, understands, affirms, denies, is willing, is unwilling, and also imagines and has sensory perceptions" (p. 19).

So, is all this misunderstanding simply poor scholarship on behalf of those like Damasio? I do not think this is the appropriate judgment. Such a judgment might be sound if it was an isolated instance, but in one form or another, this kind of "poor scholarship" seems to prevail much too mightily. It occurs too frequently, and among too many distinguished academics. While others have recognized this problem, it is usually given little attention, or attributed to "nothing but" poor scholarship. I believe that the overall phenomenon deserves to be a research topic all on its own and that some other explanation for it is required. My basic point of departure is this: Regardless of the truth of these claims, people seem to want it to be true. It is this general desire that is perhaps fueling Damasio's raucous approval. It is the allure of finding and following a new, brave pioneer, one who has managed to bridge a 400 -year-old unbridgeable chasm. This feeling, this desire, is the entry point to the Cartesian Split complex, and this needs its own framing, understanding, and interpretation.

\section{Approaching the split}

At this point, my imaginary consulting room may be invoked again, to help clarify my unique approach to this issue. The therapist believes Ash has a father complex, and fittingly, most of the stories Ash tells of Rand are simply incredulous. Ash tells stories of Rand's extreme violence, in some cases, of an almost inhuman nature. Ash also believes that Rand is responsible for pitting one half of the family against the other, such that neither side ever interacts with the other anymore. Rand is told to be very powerful, having influenced every decision made in the entire city. This is also very curious, for, according to Ash, he was also quite idiotic, easily confused, and unable to win any argument with anyone.

The therapist knows enough about human nature to know that no one human could possibly amount to that much terrible influence. Patients in therapy are often known to exaggerate their memories and personal stories. But the therapist is also skilled enough to know that it is not helpful at all to simply say, "oh come now, surely your father is not so bad. You are 
simply exaggerating, imagining it, and projecting your own problems onto the memories of your real father. The real problem is not with him, but with you."

No, such a cold and unsympathetic statement would drive Ash straight out of the consulting room and onto the next personal disaster. The statement may be essentially true, but the therapist also knows that, in spite of all these unbelievable claims, the stories feel real enough to Ash at the time. In other words, it is probably not true that Rand did those things, but, regardless, it is true that Ash remembers things that way, and so the therapist has to play along for a bit. Perhaps there is a dark part of Ash's psyche, something long forgotten and repressed, but at the same time, important for Ash's future development. Perhaps such a thing is demanding attention to itself by creating a false story out of Rand memories, disclosing itself as real by precisely not being real. The therapist must not belittle the fantasy, but rather, see where it leads.

It is the same way with our collective fantasy about Descartes. I believe in order to fully unpack the Cartesian Split complex, you have to be incredulous and trusting at the same time. In other words, it is not true that Descartes made an "abyssal separation." And yet, it is true that people uncritically believe it. In order to understand the true meaning, you have to temporarily accept this false belief. This is a very subtle position to take, and I hope this therapeutic example can be continuously recalled, in order to keep this position in mind.

Earlier, I framed this subject through the lens of Freud, via the father complex. However, I should be more clear about the full range of my influences, and my own usage of them for this study. It is better to say that my approach is not so much psychoanalytical but depth psychological. With this term, I am incorporating not just Freud but also Carl Gustav Jung, the Swiss psychologist who followed Freud. Despite their differences, both theorists employ an overall conception of the human psyche in which various unconscious forces operate independently of the conscious process, and can interfere with it, in problematic ways. This is manifested in various irrational behaviors, which can operate at both the individual and cultural levels. Such behavior is characterized by distorted perceptions of reality and preferred versions of history, even if recognized to be harmful or incomplete. Further, such behavior is unusually persistent, even after having been challenged by others. It is in these common respects that the problematic cultural interpretation of Descartes can be fruitfully understood.

My specific approach, however, is more informed by Jung than Freud. Jung distinguished his approach from Freud by minimizing the focus on frustrated biological drives, occurring only in early childhood. Although he agreed on the importance of such activity, he ultimately regarded it as a secondary influence. For Jung, the unconscious is not created from frustrated adolescence, but is pre-existing, and can also act constructively for further 
development. As part of this new model, Jung emphasized his notion of archetypes and the collective unconscious. Jung conceived of archetypes as innate structuring principles, operating at the deepest level of the psyche, and common to all humanity. They are also closely connected to the expression of human instincts. It is from this deeper, more powerful layer of the psyche, that gives the complex its power.

My approach is also influenced by James Hillman, the American psychologist who was active in the late 20th century. Hillman began his career in the Jungian school, but later played a prominent role in forming a distinct branch, named archetypal psychology. One of the distinguishing features of this approach is an increased level of attention toward the precise details of the psychological phenomenon under study. The keyword for this focus is image. Hillman (1992) warns that abstract, technical interpretations tend to become literalized and dogmatic, which can obscure important information contained in the original image (pp. 144-145).

This particular approach may be best demonstrated by example. Perhaps Ash comes to the first therapy session after having a big dream the night before. In this dream, Ash was in front of a house from the distant past, but recognizable, perhaps from childhood. Ash then looks up at the house in terror, seeing a huge, distorted image of Rand, who splits the house right down the middle. Ash's mother is feared to be inside.

In the initial session, Ash is understandably distraught recounting the details of this terrible dream. It would be a grave mistake for the therapist to say, "the splitting is merely your own father complex, reflecting your own internal dissociation." Rather, the archetypal psychologist would gently say, "tell me more about Rand's face," or, "what does the house look like now?" With this approach, the specific choices of words used by the dreamer are focused on, and not so hastily bypassed for theory. The words are understood as being pregnant with potential meaning, and studied closely. I intend to follow this approach in this book.

The approach of archetypal psychology also implies a different scope for what typically comes under the term "therapy." Hillman was trained as a personal therapist, but later was more interested in the "therapy of ideas," and his later writings reflect this. This approach would seem natural, for if archetypes are innate and universal, then they are necessarily active in all human activity, and not just in the moments of psychotherapy. In other words, anything involving human thinking is open to archetypal influence. Interestingly, this approach is contained in Jung, but not the Jung that most people are familiar with. Shamdasani (2003) argues that Jung himself intended for his ideas to be applied outside of personal therapy. Indeed, it appears he even hoped for founding of a general psychology that could be applied to any discipline whatsoever. He even appeared to have chosen a unique term for it, that of "complex psychology," within which personal therapy is only one part (pp. 13-15). From this perspective, a widespread 
cultural phenomenon of mistaken philosophical interpretation can indeed be seen as a collective activity of complexes, and also approached with a methodology particular to complexes.

\section{The complexity of complexes}

It may prove to be regrettable that Jung's offered moniker was not chosen, for there is a wealth of insight available within the term "complex." The full range of potential meanings, and their implications, is itself, well, complex. For one, the term can be taken as value-neutral, especially in Jung's formulation. Contrary to popular understanding, having a complex does not necessarily imply that something has gone wrong. In Jung's usage of the term, complexes are the basic structural units of the psyche, inherent to all its processes. Indeed, the ego is itself a complex. "A complex becomes pathological only when we think we have not got it" (Jung, 1943/1985, p. 79).

A complex can also be regarded positively, as an expression of undeveloped potential. For example, it may very well be that Rand was a bad father, but perhaps Ash's other siblings do not feel the need to blame everything on him. Perhaps in Ash's unique personal life, there is a need for some reason to develop more authoritative skills, and the potential to do so has formed a father complex around the figure of Rand, in Ash's own imagination. The complex can then be seen as a positive development, a sign that further maturation is on the way, and the pathological behavior is simply a way to ensure appropriate attention is given to the development of these latent skills.

Complexes also tend to be bipolar, able to hold a pair of conflicting ideas somehow in unison. Recall that Ash believed Rand to be almost superhumanly powerful, holding entire communities under his influence. But at the same time, Ash refers to Rand as being foolish, illogical, and incompetent, at even the most basic tasks. One wonders how such a person could actually exist, but it seems to have no problem existing in Ash's psyche. This kind of behavior alone hints at a range of unexplored meanings and potential behind the image.

Complexes tend to magnify otherwise small events into something much larger, becoming blown all out of proportion. Perhaps Ash painfully recalls a particular memory of Rand as a bad father, perhaps losing his patience one day and throwing away Ash's favorite toy. Now this event may turn out to be historically true, but most parents have regrettable moments such as this. The curious question is then: Why should Ash feel so traumatized, today, by such a commonplace event, that happened so many years ago?

Although complexes can reflect a true event, it is usually the departure from historical reality that offers the most amount of insight. Complexes often exaggerate and distort the facts to such a degree that the link to the original historical event can be very difficult to comprehend. It is more 
likely that Rand took away a small plastic toy for one day, because Ash was simply misbehaving. But perhaps the story has mutated over the years into something much more malevolent, such as Rand burning Ash's most treasured possession, and having Ash watch him do it, laughing the whole time, while Ash cried. Suddenly, an otherwise normal human being in the past has become a supervillain, something more likely to be found in a fairy tale featuring an evil sorcerer.

Another curious aspect of such a story might be Ash's insistence on its historical truth. Perhaps Ash would insist on the memory being exactly as it happened, expressing no doubts, especially when doubt in this case would be very reasonable. Most adults cannot remember events perfectly from only the prior month, much less from early childhood. But in this case, Ash may insist loudly that the events transpired exactly as recalled in memory, and any attempt to cast doubt on the veracity of the story is met with scorn and derision. Ash has suddenly become a memory expert, even if not otherwise justified, and to this we can all relate.

Complexes are not only personal but can extend easily into the collective sphere. This should seem natural, as a collection of individuals is also a collection of individual psyches, and collective events such as discussions and arguments are also psychic events. But for whatever reason, even within many Jungian scholars, complexes tend to be understood and discussed at only the personal level. This is probably related to the fact that Jungian thought has been more prolific at the therapeutic level instead of at the general academic. However, in recent years, several Jungian scholars have been exploring the notion of "cultural complexes," most prominently Singer and Kimbles, who also coined the term (Kirsch, 2004, p. 185). Although the range of application of these complexes is obviously different, the overall dynamic is remarkably similar to personal complexes, and most of the prior examples I have given with Ash also apply to groups. This is of course fitting, as I introduced the figure of Ash explicitly as a representative of Western academia.

Complexes also tend to be somewhat difficult to work with, requiring alternate modes of engagement. Often, if a complex is approached within its original frames of reference, various defense mechanisms may be activated, which prevent any real productive developments. This is one reason why dreams and other activities of the imagination are valuable in therapy. Such expressions can provide an alternate outlet for the underlying issue, such that old problems may be confronted in a new way. This is another reason for working with the Ash metaphor.

Finally, complexes tend to thrive in places where you least expect to find them. Psychotherapists themselves are certainly not immune to them. Kirsch (2004) understands the bitter 100-year feud between the Jungian and Freudian communities as a cultural complex itself. Of course, this feud resulted from a past trauma, the conveniently titled "split," between these 
two great thinkers. Also, Hillman (1978), in his Myth of Analysis, marked out early territory for his archetypal psychology by arguing that psychotherapy itself was suffering, and in need of therapy. In other words, the very language that was supposed to be able to decipher unconscious content was itself pregnant with unconscious meaning. Only, perhaps to prove his point, Hillman did not even trust the term "unconscious." If professional psychologists are unaware of their own hidden stories, even existing within their very own language, then certainly philosophers can be too.

In summary, complexes, in the Jungian sense, are certainly more than what they seem. One never has "just a father complex," but instead is invoking with those words a very wide range of potential understanding. Complexes are both pathological and promising, both true and fanciful. They can hold conflicting ideas within a single reference, and can do so both personally and collectively, and are omnipresent. All such dynamics are at play with the Cartesian Split complex, and the examples provided with Ash and Rand were written specifically to bring these dynamics to life. The connections between the Cartesian Split complex and the metaphorical story will be drawn out in more detail throughout the book. The reader may benefit from reviewing the examples above after having completed the exposition in the book.

\section{Cogito ergo non sum}

My own history with this subject extends long before my stroll through the bookstore. As an early student, I was thoroughly enamored with math and science, and for me, Descartes was a hero. I loved the precision of mathematics, and for quite some time, I was of the opinion that truth was only to be found in exact calculations. In English class, we might have read a poem, and spent the rest of the day speculating on what the author meant. Although this was interesting, I was troubled by the thought that all such opinions were inherently untrustworthy. How can anyone, including my teacher, claim to have the "right" interpretation? Could such an interpretation ever be proved to be right? And if so, what were the criteria? Worse, if it turned out that there was no such thing as a right interpretation, how were we all not just wasting our time?

By contrast, there was no such doubt with math. Two plus three was five, exactly five, and that was the right answer. This process, for me, was the epitome of elegance. I also remember well the first time I learned the Cartesian coordinate system, and how you could use it to model the behavior of natural motion. I remember going outside and throwing objects in the air, and with only a stopwatch, I could calculate how high it went, as well as the speed at which it left my hand. I could do all this with one simple equation. The realization that I could understand such a relationship, between calculations and measurement, was thrilling to me. This fascination was 
present in me as a small child and extended through most of my adult life. I graduated from college with a degree in mechanical engineering, and have been employed as an engineer ever since.

On the other hand, throughout my early life, I sometimes displayed tendencies that were opposed to these rational ideals. Throughout engineering school, I harbored a doubt that even the mathematical process, however powerful, did not lead to the ultimate truth. On the contrary, I suspected that math and science may actually inhibit the search for it. I suspected that the really big questions of life, including even the meaning of life, were far beyond what could be calculated. Out of sight from my engineering peers, I secretly read books on religion and philosophy. I even flirted with Eastern mysticism, which emphasized the profound truth of "not-knowing." One of my favorite engineering classes was on the philosophy of science, in which we briefly touched upon the parable of Plato's cave, and that the mind was more real than things. This was a profound realization for me. What if, all of those previous moments of certainty were nothing but shadows dancing on the wall?

In spite of those doubts on the side, my identity as an engineer was firmly in place, until a period of time in my early thirties. I ended up in a very dark place. Many of my life goals, that of relationships, career, and hobbies, had all ended in failure. Worse, I felt trapped in these failures, and I fell into a deep depression. I questioned many things, but in particular, I became deeply disenchanted toward my chosen career path. I believed that an exclusive emphasis on rationality had led me to a fractured state of being, where I had lost something vitally important. Worse, I felt traumatized by it, feeling as if I had little to no access to the richer, deeper aspects of personhood, such as the arts. I read more and more books on alternative subjects, and many of these identified Descartes as the singular fountainhead of a Western paradigm that had led us all astray. I fell into this narrative. One particular morning, I felt particularly incensed toward this figure of Descartes, who surely had influenced the whole of Western culture, and therefore, the whole trajectory of my life. I believed on that day that Cartesian philosophy had a fundamental flaw in it, which has troubled us, and me, ever since. The essence of the human could not possibly be thinking. Rather, the opposite must be true; the mystics and artists had it right. I scribbled in my notebook my mantra for the week: Cogito ergo non sum.

Fortunately, I was able to make it out of that depression, and I now have a much more nuanced opinion of my interests and life choices. Although continuing as an engineer, I was able to make space for the so-called "nonrational" inclinations of my being. I was very excited when I first stumbled upon Jung, for this was a discipline that appeared to offer a path for both of my interests. Jung claimed emphatically that he was a scientist, doing empirical research, but incredibly, his research topics were dreams and myths! I was completely enthralled. Within a year, I charted out a course to go to graduate school and study depth psychology, without any 
concrete vocational goals. The experience was highly educational, but also, very healing. I felt I had finally found a path that could unify two seemingly disparate parts of my personality.

It did not take long during my new coursework to encounter once again a familiar face to me, the nefarious villain Descartes. Depth psychology is considered by many to have a strong kinship to postmodernism, and most postmodern inventories into the past locate Descartes' work as a singularly tragic turn. Although I was clearly sympathetic to the overall postmodern, psychological movement, I now felt some strong reservations to this specific account. Even though I had that original mantra moment, I felt that I had since embraced a larger perspective. From this new stance, I could now sense that there was a disproportionate amount of criticism and bitterness directed toward Descartes, over and above all the other "modern" sources. This time, I was able to remember my childhood Descartes, who was not a villain, but a hero, in addition to my mantra of the week. Although I was never trained in actual Cartesian philosophy, I began to doubt Descartes could be the source of so much gone wrong. But at the same time, I fully appreciated the need for a "post-Cartesian" worldview.

After several years of pondering this, I allowed myself to ask a simple question: Was Descartes really a Cartesian? This question felt dangerous and heretical to me at the time. I felt that doubting this assertion was placing me in singular opposition against the entire Western academy. I tentatively and hesitantly did research on this question, entering it exactly as phrased above, into an internet search engine. I did not really know what I was looking for. But what I found changed everything, and led me down the path to writing this book.

\section{A complex offering}

And now, dear reader, I trust you know enough about me and my story, but I do not know enough about you. Perhaps you have also raised doubts on this popular but questionable narrative? Or perhaps you are still doubting my hypothesis? After all, as I can attest, questioning one of the Western academy's most foundational narratives is a lot to ask.

But perhaps you also know enough about psychology yourself to suspect that this is nothing but my own personal complex, being projected onto the topic. I intentionally included all the messy details of my personal story, even though they might specifically invite such a suspicion. I fully admit to having a complex, it did require therapy, and it clearly revolved around "Cartesian" topics. Although I cannot claim to be fully healed from my complex, I do feel that my experiences with the subject allow me to have a unique, more nuanced perspective on the matter, perhaps one that is needed. But what is this need? What can my own psychological musings, spurred on from my own personal difficulties and haphazard web searches, 
contribute to centuries of philosophical criticism on one of the most widely read figures of the modern era?

Essentially, what I found on that one particular web search was that I was certainly not alone. Regardless of how they came to it, I found several others who have also come to the same suspicion. Somehow, somewhere along the line, a gross mischaracterization of Descartes was generated in the academy, then accepted in the academy, and has persisted ever since. I also learned that the problem is not limited to those outside of philosophy. There are several prominent voices in academic philosophy who, according to their colleagues, have constructed and solidified a partial and highly problematic interpretation of the original writings.

Perhaps the most prominent of these arguments is Descartes' Dualism, written by Gordon Baker and Katherine Morris (2002), professors of philosophy at Oxford. This book, along with others, is what I found on my tentative internet search. Although I will expand on this work and others like it in later sections, it is worth now summarizing some of their most salient observations. Simply stated, they answered my question in the negative. "Close textual analysis does not directly support. . . that Descartes held the main tenets of so-called 'Cartesian Dualism." Additionally, they suggest that a quasi-psychological force, a phenomenon they refer to as "the Cartesian Legend," seems to be acting somewhat autonomously, perpetuating this false interpretation (pp. 1-2). Incredibly, they found that many of the quotes often used to support this interpretation often contain within them elements that contradict it (p. 23). The "real" Descartes, if such a thing can even be conceived, may actually be farther away than ever.

At the same time, from a psychological perspective, the "unreal" Descartes is as real as ever. If there is a consistently flawed interpretation, with persistence and irony, even among the professionals, then there is very likely to be some kind of psychological mechanism involved. I will eventually leave it up to the philosophers to discover the "real" Descartes, but before such an effort can be made, I consider it fruitful to understand all possible mechanisms that have precluded the discovery in the first place. Baker and Morris's book is a work in philosophy, but the "Legend" clearly invites a psychological lens, particularly a depth psychological lens. Although they do a masterful job of describing the phenomenon from within their own framework, they are necessarily limited in fully exploring it, on its own terms. Essentially, this book is an attempt to do just that, and this is my hopeful contribution toward the ongoing discussion. My own complex has led me to such an investigation. Whatever has led you to me, let us now investigate together.

\section{Outline of chapters}

In the second and third chapters, I present the most prominent source material of the Cartesian Split cultural complex. This consists of all the various distortions, inaccuracies, and problematic interpretations. Thus far, I have 
provided brief justifications as to why such material can be considered as a complex. This overall justification will be further developed throughout the book, but the primary goal of these chapters is to simply document the material, at face value. In other words, it is best at this time to simply inventory and summarize the prominent commentary on the subject, regardless of whether or not the claims are factually true. This is the listening stage of the therapy. Occasionally, however, I will present some challenges to the claims, in order to demonstrate how it is part of a complex. Hopefully, throughout these chapters, the complex will progressively resemble more of a myth, something being uncovered from underneath the claims.

The fourth chapter summarizes the commentary of those who have recognized the overall misunderstanding but have left certain gaps in developing it. These sources are mostly from dedicated scholars of philosophy. Generally, past commentators either do not see it as much of problem, or do not fully appreciate the psychological nuances, and this is what I hope to supplement. I will also show that the matter is gaining attention, and as part of this, some have even employed a certain psychological approach, if without all the professional accoutrements, and without the necessary next steps. The remaining gaps and connections will be filled in as needed, in order to set up the remaining work.

In the fifth chapter, I delve into comparable activities of our collective imagination, specifically that of myth, in order to gain perspective on this new cultural product, the Cartesian myth. The human mind, for all its complexities, often demonstrates remarkable similarities, or patterns, in its various products. This can be shown to be the case between cultures separated from each other, in both time and space. Naturally, this draws heavily on archetypal theory, which I will also introduce in more detail, before such an inventory. I also analyze the Cartesian myth in terms of its essential features and present it as a composite of two different mythical strands.

The sixth chapter is the most psychological, in which I investigate the core meaning of the Cartesian Split cultural complex. In other words, the mythic strands are translated and interpreted into modern-day psychological terminology, specifically psychodynamic terminology used by Freud and Jung. While this move may be controversial, or perhaps somewhat arcane to outside audiences, I will demonstrate how it nonetheless offers a necessary additional perspective.

The seventh chapter attempts to locate the particular instance of this complex against a particular cultural context. It will be shown that the complex is more restrictive than is commonly assumed, and that these restrictions can be focused on in order to understand the subject more fully. In the process, however, various cultural and historical complexities are introduced, which perhaps complicate the study. As such, this chapter is highly speculative but suffices as at least a starting point for further investigation.

The eighth and final chapter serves two purposes. The first is to review and summarize the primary material and conclusions drawn throughout 
the book. The second is to revisit the original subject matter, the original words put on paper, concerning the now infamous substance dualism. My hope is that through the process of re-evaluation, a new perspective on an old topic yields fresh insight, perhaps toward our relevant needs today.

\section{References}

Baker, G. P., \& Morris, K. J. (2002). Descartes' dualism. London, UK: Routledge. Bracken, H. M. (2002). Descartes. Oxford, UK: Oneworld.

Coppin, J., \& Nelson, E. (2005). The art of inquiry: A depth psychological perspective (2nd ed.). Putnam, CT: Spring Publication.

Damasio, A. R. (1995). Descartes error: Emotion, reason and the human brain. New York, NY: Avon Books.

Damasio, A. R. (2006). Descartes error: Emotion, reason and the human brain. London, UK: Vintage Books.

Dennett, D. (1995). Review of Damasio, Descartes' error. In Times literary supplement (pp. 3-4). Retrieved from: https://ase.tufts.edu/cogstud/dennett/papers/ damasio.htm

Descartes Error-Mixed Mental Arts-T-Shirt I TeePublic. (2019, November 6). Retrieved November 6, 2019, from TeePublic website: https://www.teepublic. $\mathrm{com} / \mathrm{t}$-shirt/1232748-descartes-error

Descartes, R. (1984). The philosophical writings of Descartes (Vol. 2; J. Cottingham, R. Stoothoff, \& D. Murdoch, Trans.). Cambridge, UK: Cambridge University Press.

Devlin, K. (1998). Goodbye, Descartes: The end of logic and the search for a new cosmology of the mind. New York, NY: Wiley.

Gaukroger, S. (1998). Descartes: An intellectual biography. Oxford, UK: Clarendon Press.

Hillman, J. (1978). The myth of analysis: Three essays in archetypal psychology. New York, NY: Harper Colophon.

Hillman, J. (1992). Re-visioning psychology. New York, NY: Harper Perennial.

Jung, C. G. (1985). Psychotherapy and a philosophy of life. In R. F. C. Hull (Trans.), The collected works of C. G. Jung (Vol. 16, pp. 76-83). Princeton, NJ: Princeton University Press. (Original work published 1943)

Kirsch, T. (2004). Cultural complexes in the history of Jung, Freud and their followers. In T. Singer \& S. L. Kimbles (Eds.), The cultural complex: Contemporary Jungian perspectives on psyche and society (pp. 185-195). London, UK: Routledge.

McCann, G., \& Bechsgaard, G. (2018, September 30). It's time to break up with Descartes. Retrieved February 10, 2019, from Psychology Today website: https://www.psychologytoday.com/blog/return-stillness/201809/its-time-breakdescartes

Percy, W. (1999). Love in the ruins: The adventures of a bad Catholic at a time near the end of the world. New York, NY: Picador.

Shamdasani, S. (2003). Jung and the making of modern psychology: The dream of a science. Cambridge, UK: Cambridge University Press.

Abram, D. (1997). The spell of the sensuous: Perception and language in a more-than-human world. New York, NY: Vintage Books. 
Abram, D. (2002). Foreword. In Radical ecopsychology: Psychology in the service of life (pp. ix-xi). Albany: State University of New York Press.

Ariew, R. (1992). Descartes and scholasticism: The intellectual background to Descartes' thought. In J. Cottingham (Ed.), The Cambridge companion to Descartes (pp. 58-90). Cambridge, UK: Cambridge University Press.

Atwood, G. E., Stolorow, R. D., \& Orange, D. M. (2011). The madness and genius of post-Cartesian philosophy: A distant mirror. The Psychoanalytic Review, 98(3), 263-285. doi: 10.1521/prev.2011.98.3.263

Avens, R. (1988). The subtle realm: Corbin, Sufism and Swedenborg. In R. Larsen (Ed.), Emanuel Swedenborg: A continuing vision: A pictorial biography \& anthology of essays \& poetry (pp. 382-391). New York, NY: Swedenborg Foundation.

Baker, G. P., \& Morris, K. J. (2002). Descartes' dualism. London, UK: Routledge.

Balzac, S. (2008). Tips for parents: Cartesian splits and Chinese splits. Davidson Institute for Talent Development. Retrieved from: https:/www.davidsongifted. org/Search-Database/entry/A10519

Bankart, C. P. (2006). Treating anger with wisdom and compassion: A buddhist approach. In E. L. Feindler (Ed.), Anger related disorders: A practitioner's guide to comparative treatments (2006-05844-011; pp. 231-255). Springer; psyh. Retrieved from: http://pgi.idm.oclc.org/login?url=http://search.ebscohost.com/ login. aspx ?direct=true \&db=psyh\&AN=2006-05844-011\&site=ehost-live $\&$ scope $=$ site

Barron, R. (2015, June 9). Bruce Jenner, the "shadow council," and St. Irenaeus. Word on fire. Retrieved from: https://www.wordonfire.org/resources/article/ bruce-jenner-the-shadow-council-and-st-irenaeus/4785/

Bateson, G. (1979). Mind and nature: A necessary unity (1st ed.). New York, NY: Dutton.

Bateson, G. (2000). Steps to an ecology of mind. Chicago, IL: University of Chicago Press.

Bendelow, G. (2006). Pain, suffering and risk. Health, Risk and Society, 8(1), 59-70.

Benjamin, J. (2004). Beyond doer and done to: An intersubjective view of thirdness. Psychoanalytic Quarterly, 73, 5-46.

Berman, M. (1981). The reenchantment of the world. Ithaca, NY: Cornell University Press.

Bordo, S. (1987). The flight to objectivity: Essays on Cartesianism and culture. Albany: State University of New York Press.

Bordo, S. (1999). Introduction. In S. Bordo (Ed.), Feminist interpretations of René Descartes (pp. 1-25). University Park: Pennsylvania State University Press.

Brady, R. (1977). Goethe's natural science: Some non-Cartesian meditations. Toward a Man-Centered Science, 1, 137-165.

Brady, R. (1981). Minds, models and Cartesian observers: A note on conceptual problems. Journal of Social and Biological Structures, 4(3), 277-286.

Bray, A., \& Colebrook, C. (1998). The haunted flesh: Corporeal feminism and the politics of (dis)embodiment. Signs: Journal of Women in Culture and Society, 24(1), 35-67. doi: 10.1086/495317

Brencick, J. M. (1997). Universality and singularity: A philosophy of nursing (UMI 9804624) [Doctoral dissertation]. ProQuest Dissertations and Theses.

Bright, B. (2015). Culture collapse disorder: Ecopsychopathy, exile, and the end of home (UMI 3684129) [Doctoral dissertation]. ProQuest Dissertations and Theses. 
Busch, E. K., \& Lawler, P. A. (2009). Democracy reconsidered. Lanham, MD: Lexington Books.

Capra, F. (1983). The turning point: Science, society, and the rising culture. New York, NY: Bantam Books.

Cee, V. (2013). The end(s) of advocacy: Responding to our own mandates instead of creating new leadership. Action, Criticism, and Theory for Music Education, $12(1), 64-81$.

Cody, T. (2016). Lillian Smith, Richard Wright, and Walker Percy's ontological vision: Gnosticism, Cartesian dualism, and the split of the Southern self. Theses and Dissertations. Retrieved from: https://scholarcommons.sc.edu/etd/3461

Colman, W. (2015). Bounded in a nutshell and a king of infinite space: The embodied self and its intentional world: The embodied self and its intentional world. Journal of Analytical Psychology, 60(3), 316-335. doi: 10.1111/1468-5922.12152

Conway, M., \& Pratt, N. (2019, February 10). Art in general. Retrieved from: http://www.artingeneral.org/exhibitions/237

Cortesi, T. (2013). "Traitorous bodies": Cartesian dualism in romance novels by Susan Johnson and E.L. James [Master's Thesis]. Texas State University.

Cottingham, J. (1998). Descartes' treatment of animals. In J. Cottingham (Ed.), Descartes (pp. 225-233). Oxford, UK: Oxford University Press.

Cushman, P. (2011). So who's asking? Politics, hermeneutics, and individuality. In R. Frie \& W. J. Coburn (Eds.), Persons in context: The challenge of individuality in theory and practice (2010-09131-002; Vol. 32, pp. 21-40). Routledge/Taylor \& Francis; PsycINFO. Retrieved from: http://pgi.idm.oclc.org/login?url=http://search.ebscohost.com/login. aspx?direct=true\&db=psyh\&AN=2010-09131-002\&site=ehost-live\&scope=site de Quincey, C. (2008). Reality bubbles: Can we know anything about the physical world? Journal of Consciousness Studies, 15(8), 94-101.

Dennett, D. (1995). Review of Damasio, Descartes' error. In Times Literary Supplement (pp. 3-4). Times Newspapers Ltd. Retrieved from: https://ase.tufts.edu/ cogstud/dennett/papers/damasio.htm

Dyson, M. E. (2001). When you divide body and soul, problems multiply: The black church and sex. In R. P. Byrd \& B. Guy-Sheftall (Eds.), Traps: African American Men on Gender and Sexuality (pp. 308-326). Bloomington: Indiana University Press.

Fenwick, S. M. (1998). The dreaming earth: Foundations for a process-oriented approach to ecopsychology. (UMI 9910825) [Doctoral dissertation]. ProQuest Dissertations and Theses.

Fisanick, C. L. (2003). The embodied pedagogue: Teaching and writing with the body (UMI 3099577) [Doctoral dissertation]. ProQuest Dissertations and Theses.

Fisher, A. (2002). Radical ecopsychology: Psychology in the service of life. Albany: State University of New York Press.

Forsman, J. (2015). Did Descartes kick dogs? Some words on the Cartesian conception of animals. Retrieved from: https://www.academia.edu/31979299/Did_ Descartes_kick_dogs_Some_words_on_the_Cartesian_conception_of_animals Gallop, J. (1988). Thinking through the body. New York, NY: Columbia University Press.

Gaukroger, S. (1998). Descartes: An intellectual biography. Oxford, UK: Clarendon Press.

Gilman, S. L. (1993). Hysteria beyond Freud. Berkeley: University of California Press. 
Goebel, E. (2014). The one-way road of aging: On Jean Améry's essay über das altern. The Germanic Review, 89(2), 202-211. eoah.

Goodrich, A. (2004). Scaling culture: Rock climbing and the embodied nature of spatial knowledge. Anthropology Southern Africa, 27(1-2), 27-34. eoah.

Graffman, E. (2017). On Gregory Bateson's epistemology, his definition of mind, and its solution to the Cartesian dualism or mind-body problem. Rocznik Naukowy Kujawsko-Pomorskiej Szkoly Wyższej w Bydgoszczy. Transdyscyplinarne Studia o Kulturze (i) Edukacji, 12, 146-157.

Gragg, A. (1973). Charles Hartshorne. Word Books. Retrieved from: http://www. religion-online.org/book/charles-hartshorne/

Güzeldere, G., \& Franchi, S. (1995). Mindless mechanisms, mindful constructions. Stanford Electronic Humanities Review, 4(2). Retrieved from: http://web. stanford.edu/group/SHR/4-2/text/introduction.html\#note3

Hannah, B. (1976). Jung, his life and work: A biographical memoir. New York, NY: Putnam.

Hoeppe, G. (2015). Representing representation. Science, Technology and Human Values, 40(6), 1077-1092. eoah.

Hollomon, D. (2000). The "I" of the therapist: Eastern mindfulness and the skillful use of self in psychotherapy. (UMI 9976891) [Doctoral dissertation]. ProQuest Dissertations and Theses.

Iltis, C. (1973). The decline of Cartesianism in mechanics: The LeibnizianCartesian debates. Isis, 64(3), 356-373.

Isaacs, W. N. (2001). Toward an action theory of dialogue. International Journal of Public Administration, 24(7-8), 709-748. eoah.

James, G. (2019, July 5). Neuroscience says your body and mind get stronger when you focus on this one thing. Inc.Com. Retrieved from: https://www.inc. com/geoffrey-james/neuroscience-says-your-body-mind-get-stronger-when-youfocus-on-this-one-thingdraft-1562273865.html

Jolley, N. (1992). The reception of Descartes' philosophy. In J. Cottingham (Ed.), The Cambridge companion to Descartes (pp. 393-423). Cambridge, UK: Cambridge University Press.

Kavanagh, A. M., \& Broom, D. H. (1998). Embodied risk: My body, myself? Social Science and Medicine, 46(3), 437-444. doi: 10.1016/S0277-9536(97)00188-3

Kellogg, C. (2013). Road back to recovery: Hermeneutic phenomenological inquiry into psychotropic medication management. doi: 10.1037/e621642013-001

Kelso, C. (2015, February 10). Reuniting the apparent mind/body split. The Deepest Peace. Retrieved from: https://thedeepestpeace.com/2015/02/10/ reuniting-the-apparent-mindbody-split/\#more-413

Koestler, A. (1964). The act of creation. London, UK: Hutchinson \& Co.

Koopman, K. (2019, February 10). Cartesian split (excerpt). Retrieved from: https://soundcloud.com/athrynoopman/cartesian-split-excerpt

Kureethadam, J. I. (2017). The philosophical roots of the ecological crisis: Descartes and the modern worldview. Newcastle upon Tyne, UK: Cambridge Scholars Publishing.

Lapointe, F. H. (1976). The existence of alter egos: Jean-Paul Sartre and Maurice Merleau-Ponty. Journal of Phenomenological Psychology, 6(2), 209-216. psyh. doi: 10.1163/156916276X00089

Lee, K. (2013). Reading Descartes otherwise: Blind, mad, dreamy, and bad. New York, NY: Fordham University Press. 
Lerner, R. (1999). Review of the book Synthesizing nature-nurture: Prenatal roots of instinctive behavior by G. Gottlieb. International Journal of Behavioral Development, 23(1), 265-272. eoah.

Lipton, B. H. (2008). The biology of belief: Unleashing the power of consciousness, matter \& miracles. Carlsbad, CA: Hay House.

Lloyd, G. (1993). The man of reason: Male and "female" in western philosophy (2nd ed.). London, UK: Routledge.

Lloyd, R. J. (2011). Awakening movement consciousness in the physical landscapes of literacy: Leaving, reading and being moved by one's trace. Phenomenology \& Practice, 5(2), 73-92. doi: 10.29173/pandpr19846

Lock, M. (2002). Inventing a new death and making it believable. Anthropology and Medicine, 9(2), 97-115. eoah.

Lokhorst, G. (2016). Descartes and the pineal gland. In E. N. Zalta (Ed.), The Stanford encyclopedia of philosophy. Retrieved from: http://plato.stanford.edu/ archives/sum2016/entries/pineal-gland/

Lovejoy, A. O. (1955). The revolt against dualism: An inquiry concerning the existence of ideas. LaSalle, IL: Open Court Publishing.

Maddock, M., \& Humphries, M. (2010). Perspectives on the social implications of developments in quantum physics with a focus on reuniting the Cartesian split. Organization, Identity and Locality (OIL) VI: Critical Studies of Managementand Organizing in Aotearoa/New Zealand, 52-57. Retrieved from: http://citeseerx.ist. psu.edu/viewdoc/download?doi=10.1.1.456.9464\&rep=rep1\&type=pdf\#page=52

Maguire, R. (1997). "Proofs of God's existence:” Walker Percy, Jacques Maritain, and the problem of the symbol in the moviegoer. Logos: A Journal of Catholic Thought and Culture, 1(3), 69-79. doi: 10.1353/log.1997.0018

Makari, G. (2009). Revolution in mind: The creation of psychoanalysis. New York, NY: Harper Perennial.

Marshall, P. J. (2015). Neuroscience, embodiment, and development. In W. F. Overton, P. C. M. Molenaar, \& R. M. Lerner (Eds.), Handbook of child psychology and developmental science, Vol. 1: Theory and method (7th ed.) (2015-15498-007; pp. 244-283). Wiley; psyh. Retrieved from: http://pgi.idm.oclc.org/login? url=http://search.ebscohost.com/login. aspx?direct=true \& db=psyh\&AN=2015-15498-007\& 2 ite=ehost-live\&scope=site

Metzger, J. G. (1987). Narration as a construct for understanding third-culture building: Exploring missionaries' success and effectiveness as cosmological change agents (UMI DP22421) [Doctoral dissertation]. ProQuest Dissertations and Theses.

Mills, B. (2006). Jung and the African diaspora. Western Journal of Black Studies, $30(2), 84-88$.

Mkhatshwa, E. (2010). Authorial intention and agency in Luke's Acts. Outeursintensie En Handelingsrol in Lukas Se Handelinge, 31(1), 99-122.

Mortimore, L. (2013). Embodied ways of knowing: Women's eco-activism (Accession or Order No. NS28393) [Doctoral dissertation]. ProQuest Dissertations and Theses.

Nepil, J. (n.d.). The Cartesian demiurge. Retrieved February 17, 2019, from https:// catholicstuffpodcast.com/podcast/2014/12/01/the-cartesian-demiurge.html

Obeyesekere, G. (2012). The awakened ones: Phenomenology of visionary experience. New York, NY: Columbia University Press.

Orning, S. E. S. (2012). Fleshly embodiments: Early modern monsters, Victorian freaks, and twentieth-century affective spectatorship (UMI 3521806) [Doctoral 
dissertation]. ProQuest Dissertations and Theses.

Orr, D. (2007). Feminist politics: Identity, difference, and agency. Lanham, MD: Rowman \& Littlefield.

Overton, W. F. (2013). A new paradigm for developmental science: Relationism and relational-developmental systems. Applied Developmental Science, 17(2), 94-107. eoah.

Paul II, P. J. \& Messori, V. (1994). Crossing the threshold of hope. Knopf. Retrieved from: http://search.ebscohost.com/login. aspx?direct=true\&scope $=$ site $\& \mathrm{db}=$ nlebk $\& \mathrm{db}=$ nlabk\&AN=718803

Percy, W. (1990). The fateful rift: The San Andreas fault in the modern mind. Design for Arts in Education, 91(3), 2-7, 51-53.

Pether, P. (1999). On foreign ground: Grand narratives, situated specificities, and the praxis of critical theory and law. Law and Critique, 10(3), 211-236. eoah.

Poloma, M. M. (2003). Main street mystics: The Toronto blessing and reviving pentecostalism. Walnut Creek, CA: Altamira.

Pope, C. (2011, April 5). On the Cartesian anxiety of our times and what faith can offer. Community in Mission. Retrieved from: http://blog.adw.org/2011/04/ on-the-cartesian-anxiety-of-our-times-and-what-faith-can-offer/

Potter, B. (2011). The hallowed in the hollow: Aesthetic elements of the sublime in the Cartesian unworld. Avello Publishing Journal, 1(1), 23-42.

Reid-Pharr, R. (1999). Conjugal union: The body, the house, and the black American. New York, NY: Oxford University Press.

Rosado, C. (2008). Context determines content: Quantum physics as a framework for "wholeness" in urban transformation. Urban Studies, 45(10), 2075-2097.

Schwyzer, H. (1997). Subjectivity in Descartes and Kant. The Philosophical Quarterly, 47(188), 342-357.

Scienceandnonduality. (2015, December 16). Cartesianism as the effect of our collective childhood trauma, Edward Frenkel. Retrieved from: https://www. youtube.com/watch?v=t_iE04ggR9w

Seidl, C. (2013, January 10). The Cartesian paradigm. Retrieved from: http://www. carlaseidl.com/2013/the-cartesian-paradigm/

Shapiro, Y. (2015). Dynamical systems therapy (DST): Theory and practical applications. Psychoanalytic Dialogues, 25(1), 83-107. eoah.

Sheldrake, R. (2012). Science set free: 10 paths to new discovery. New York, NY: Deepak Chopra Books.

Silverstein, C. M. (2003). Looking back to the future in nursing science development from 1952-2002: A historical perspective (UMI 3091294) [Doctoral dissertation]. ProQuest Dissertations and Theses.

Sjöstedt-H, P. (2018). Panpsychism: Ubiquitous sentience. High Existence, 1.

Skrbina, D. (2007). Beyond Descartes: Panpsychism revisited. Axiomathes, 16(4), 387-423. doi: 10.1007/s10516-005-8708-3

Small, C. (1998). Musicking: The meanings of performing and listening. Middletown, CT: Wesleyan University Press.

Smith, A. P. (2011, October). Do we need an absolute? Do We Need an Absolute? Retrieved from: http://www.integralworld.net/smith35.html

Smith, J. K. (1985). Review of Bernstein: Beyond objectivism and relativism. Phenomenology + Pedagogy, 3(1), 60-64.

Smith, M. B. (2015). William James. In J. D. Wright (Ed.), International encyclopedia of the social \& behavioral sciences (2nd ed., pp. 786-790). Elsevier. 
Snyder, G. (2001). The practice of the wild: Essays. New York, NY: North Point Press.

Sorell, T. (2005). Descartes reinvented. Cambridge, UK: Cambridge University Press.

Spuybroek, L. (1999). The Cartesian split. ANY: Architecture New York, 24, 13-13. JSTOR.

Steelman, T. (2018, February 11). Cartesian self vs. Ecological self. Medium. Retrieved from: https://medium.com/@taylor.steelman.ot/what-is-the-mostdangerous-thing-in-existence-bb55294391c6

Stern, K. (1999). Descartes. In S. Bordo (Ed.), Feminist interpretations of René Descartes (pp. 29-47). University Park, PA: Pennsylvania State University Press.

Stolorow, R. D. (2013). Heidegger and post-Cartesian psychoanalysis: My personal, psychoanalytic, and philosophical sojourn. Humanistic Psychologist, 41(3), 209-218. doi: 10.1080/08873267.2012.724266

Storm, S. (2015). An elegy on species obituaries (UMI 10001004) [Master's Thesis]. ProQuest Dissertations and Theses.

Temple, W. (1934). Nature, man and God. Edinburgh, UK: R. \& R. Clark, Limited.

Temple-Hoon, J. (2012). Returning to the labyrinth: The sacrificial body in Cartesian philosophy, phenomenology, and the myth of Ariadne and Theseus (UMI 3065325) [Doctoral dissertation].

Thayer, L. L. (2009). The adoption of shamanic healing into the biomedical health care system in the United States. (UMI AAI3359161) [Doctoral dissertation]. ProQuest Information and Learning.

Thayer, V. T. (1919). A comparison of Bergson and Spinoza: With reference to their conceptions of reality and knowledge. The Monist, 29(1), 96-105. JSTOR.

Thomas, C. C. S. (1996). The allure of determinacy: Truth and Cartesian certainty (UMI 9625960) [Doctoral dissertation]. ProQuest Dissertations and Theses.

Tomos, Y. (2013). The significance of anime as a novel animation form, referencing selected works by Hayao Miyazaki, Satoshi Kon and Mamoru Oshii [Doctoral dissertation]. Aberystwth University.

Valadas Ponte, D., \& Schäfer, L. (2013). Carl Gustav Jung, quantum physics and the spiritual mind: A mystical vision of the twenty-first century. Behavioral Sciences, 3(4), 601-618. doi: 10.3390/bs3040601

van Dijk, J., \& Hummels, C. (2017). Designing for embodied being-in-the-world: Two cases, seven principles and one framework. Proceedings of the Tenth International Conference on Tangible, Embedded, and Embodied Interaction - TEI', 17, 47-56. doi: 10.1145/3024969.3025007

Vertinsky, P. (2001). A militant madonna: Charlotte Perkins Gilman-Feminism and physical culture. The International Journal of the History of Sport, 18(1), 55-72. eoah.

Voltaire, F.-M. (1901). Theworks of Voltaire, a contemporaryversion (W. F. Fleming, Trans.). Retrieved from: http://archive.org/details/worksofvoltairec12volt von Franz, M.-L. (1992). Psyche and matter. Boston, MA and London, UK: Shambhala.

Washburn, T. (2012). Healing the Cartesian split: Understanding and renewing pathos in academic writing [Master's Thesis]. Retrieved from: http:// scholarsarchive.byu.edu/etd/3671

Watson, R. A. (1998). The breakdown of Cartesian metaphysics. Indianapolis, IN: Hackett. 
Whitehead, A. N. (1938). Modes of thought. New York, NY: The Macmillan Company.

Whitehead, A. N. (1979). Process and reality: An essay in cosmology (D. R. Griffin \& D. W. Sherburne, Eds.). New York, NY: Free Press.

Wilde, S. (2013). Care in education: Teaching with understanding and compassion. New York, NY: Routledge.

aquinasonline. (n.d.). Retrieved June 1, 2016, from: http://www.aquinasonline. com/Questions/women.html

Baker, G. P., \& Morris, K. J. (2002). Descartes' dualism. New York, NY: Routledge.

Berman, M. (1981). The reenchantment of the world. Ithaca, NY: Cornell University Press.

Bordo, S. (1987). The flight to objectivity: Essays on Cartesianism and culture. New York: State University of New York Press.

Capra, F. (1983). The turning point: Science, society, and the rising culture. Toronto, Canada and New York, NY: Bantam Books.

Cole, J. R. (1992). The Olympian dreams and youthful rebellion of René Descartes. Chicago, IL: University of Illinois Press.

Cottingham, J. (1998). Introduction. In J. Cottingham (Ed.), Descartes (pp. 1-27). New York, NY: Oxford University Press.

Dennett, D. (1991). Consciousness explained. Boston, MA: Back Bay Books.

Hillman, J. (1992a). Anima mundi: The return of the soul to the world. In J. Hillman (Ed.), The thought of the heart and the soul of the world (pp. 89-130). Dallas, TX: Spring.

Hillman, J. (1992b). Re-visioning psychology. New York, NY: Harper Perennial.

Hillman, J. (2007). Apollo, dream, reality. In J. Hillman (Ed.), Mythic figures (pp. 320-335). Putnam, CT: Spring.

Josephson-Storm, J. A. (2017). The myth of disenchantment: Magic, modernity, and the birth of the human sciences (1st ed.). Chicago, IL: University of Chicago Press.

Lovejoy, A. O. (1955). The revolt against dualism: An inquiry concerning the existence of ideas. LaSalle, IL: Open Court Publishing.

Olson, R. (2013). Psyche as postmodern condition: The situation of metaphor in James Hillman's archetypal psychology. Janus Head, 13(12), 61-91.

Rorty, R. (1980). Philosophy and the mirror of nature. Princeton, NJ: Princeton University Press.

Russell, D. (2013). The life and ideas of James Hillman. New York, NY: Helios Press.

Ryle, G. (1966). The concept of mind. London, UK: Hutchinson's.

Short, B. (2018). The depths of the Cartesian split: A hidden myth in modern psychology (10822143) [Doctoral dissertation]. Pacifica Graduate Institute.

Ariew, R. (1992). Descartes and scholasticism: The intellectual background to Descartes' thought. In J. Cottingham (Ed.), The Cambridge companion to Descartes (pp. 58-90). Cambridge, UK: Cambridge University Press.

Baker, G. P., \& Morris, K. J. (2002). Descartes' dualism. London, UK: Routledge.

Bennett, J. (1998). Descartes' theory of modality. In J. Cottingham (Ed.), Descartes (pp. 160-185). Oxford, UK: Oxford University Press.

Bolton, R. (1999). Dualism and the philosophy of the soul. Sacred Web, 4. Retrieved from: http://www.sacredweb.com/online_articles/sw4_bolton.html 
Bracken, H. M. (2002). Descartes. Oxford, UK: Oneworld.

Cottingham, J. (1992). Introduction. In J. Cottingham (Ed.), The Cambridge companion to Descartes (pp. 1-20). Cambridge, UK: Cambridge University Press.

Cottingham, J. (1998a). Descartes' treatment of animals. In J. Cottingham (Ed.), Descartes (pp. 225-233). Oxford, UK: Oxford University Press.

Cottingham, J. (1998b). Introduction. In J. Cottingham (Ed.), Descartes (pp. 1-27). Oxford, UK: Oxford University Press.

De Rosa, R. (2007). The myth of Cartesian qualia. Pacific Philosophical Quarterly, 88(2), 181-207. doi: 10.1111/j.1468-0114.2007.00286.x

Garber, D. (1998). Descartes' method and the role of experiment. In J. Cottingham (Ed.), Descartes (pp. 234-258). Oxford, UK: Oxford University Press.

Lee, K. (2013). Reading Descartes otherwise: Blind, mad, dreamy, and bad. New York, NY: Fordham University Press.

Markie, P. (1998). The cogito and its importance. In J. Cottingham (Ed.), Descartes (pp. 50-78). Oxford, UK: Oxford University Press.

Paley, J. (2002). The Cartesian melodrama in nursing. Nursing Philosophy, 3, 189-192.

Rodis-Lewis, G. (1998). Descartes and the unity of the human being. In J. Cottingham (Ed.), Descartes (pp. 197-210). Oxford, UK: Oxford University Press.

Rorty, A. O. (1992). Descartes on thinking with the body. In J. Cottingham (Ed.), The Cambridge companion to Descartes (pp. 371-292). Cambridge, UK: Cambridge University Press.

Ryle, G. (1966). The concept of mind. London, UK: Hutchinson's.

Sorell, T. (2005). Descartes reinvented. Cambridge, UK: Cambridge University Press.

Wilson, M. D. (1998). The epistemological argument for mind-body distinctness. In J. Cottingham (Ed.), Descartes (pp. 186-196). Oxford, UK: Oxford University Press.

Baker, G. P., \& Morris, K. J. (2002). Descartes' dualism. London, UK: Routledge.

Bordo, S. (1987). The flight to objectivity: Essays on Cartesianism and culture. Albany, NY: State University of New York Press.

Campbell, J. (1973). The hero with a thousand faces (2nd ed.). Princeton, NJ: Princeton University Press.

Cottingham, J. (1998). Introduction. In J. Cottingham (Ed.), Descartes (pp. 1-27). Oxford, UK: Oxford University Press.

Hardacre, H. (2017). Shinto: A history. New York, NY: Oxford University Press.

Hoeller, S. A. (1989). Jung and the lost gospels: Insights into the Dead Sea scrolls and the Nag Hammadi library. Wheaton, IL: Theosophical.

Jonas, H. (1972). The Gnostic religion: The message of the alien god and the beginnings of Christianity (2nd ed.). Boston, MA: Beacon Press.

Meyer, M. (Ed.). (2007). The Nag Hammadi scriptures. San Francisco, CA: HarperSanFrancisco.

Meyer, M., \& Pagels, E. H. (2007). Introduction. In M. Meyer (Ed.), The Nag Hammadi scriptures (pp. 1-13). San Francisco, CA: HarperSanFrancisco.

Pinch, G. (2004). Egyptian mythology: A guide to the gods, goddesses, and traditions of ancient Egypt. Oxford, UK: Oxford University Press.

Plato. (1952a). Symposium. In B. Jowett (Trans.), Great books of the western world, vol. 7 Plato (pp. 149-173). Chicago, IL: William Benton, Encyclopedia Britannica. 
Plato. (1952b). Timaeus. In B. Jowett (Trans.), Great books of the western world, vol. 7 Plato (pp. 442-477). Chicago, IL: William Benton, Encyclopedia Britannica.

Rodis-Lewis, G. (1998). Descartes and the unity of the human being. In J. Cottingham (Ed.), Descartes (pp. 197-210). Oxford, UK: Oxford University Press.

Thomas, C. C. S. (1996). The allure of determinacy: Truth and Cartesian certainty (Doctoral dissertation). Retrieved from ProQuest Dissertations and Theses. (UMI 9625960)

von Franz, M.-L. (1972). Patterns of creativity mirrored in creation myths. Dallas, TX: Spring.

Zeyl, D. (2014). Plato's Timaeus. In E. N. Zalta (Ed.), The Stanford encyclopedia of philosophy. Retrieved from: https://plato.stanford.edu/archives/spr2014/ entries/plato-timaeus/

Baker, G. P., \& Morris, K. J. (2002). Descartes' dualism. London, UK: Routledge.

Berman, M. (1981). The reenchantment of the world. Ithaca, NY: Cornell University Press.

Brook, J. A. (1992). Freud and splitting. International Review of Psycho-Analysis, 19, 335-350.

Campbell, J. (1983). Historical atlas of world mythology. New York, NY: Harper \& Row.

Edinger, E. F. (1984). The creation of consciousness: Jung's myth for modern man. Toronto, Canada: Inner City Books.

Erlanger, O., \& Govela, L. O. (2018, November 27). The origins of Silicon Valley's garage myth. Retrieved October 20, 2019, from Fast Company website: https:// www.fastcompany.com/90270226/the-origins-of-silicon-valleys-garage-myth

Freud, S. (1964). An outline of psycho-analysis. In J. Strachey (Ed.), Moses and monotheism: An outline of psycho-analysis and other works (pp. 141-208). London, UK: Hogarth Press. (Original work published 1940)

Freud, S. (1964). Splitting of the ego in the process of defence. In J. Strachey (Ed.), Moses and monotheism: An outline of psycho-analysis and other works (pp. 271-278). London, UK: Hogarth Press. (Original work published 1938)

Hoeller, S. A. (1982). The gnostic Jung and the seven sermons to the dead (1st ed.). Wheaton, IL: Theosophical Pub. House.

Jacobi, J. (1968). The psychology of C. G. Jung: An introduction with illustrations. New Haven, CT: Yale University Press.

Jung, C. G. (1960). Mental disease and the psyche. In R. F. C. Hull (Trans.), The collected works of C. G. Jung (Vol. 3, pp. 226-230). Princeton, NJ: Princeton University Press. (Original work published 1928)

Jung, C. G. (1960). On the psychogenesis of schizophrenia. In R. F. C. Hull (Trans.), The collected works of C. G. Jung (Vol. 3, pp. 233-249). Princeton, NJ: Princeton University Press. (Original work published 1939)

Jung, C. G. (1969). A review of the complex theory. In R. F. C. Hull (Trans.), The collected works of C. G. Jung (Vol. 8, pp. 92-104). Princeton, NJ: Princeton University Press. (Original work published 1934)

Jung, C. G. (1969). Aion: Researches into the phenomenology of the self (R. F. C. Hull, Trans.). Princeton, NJ: Princeton University Press. (Original work published 1950) 
Jung, C. G. (1969). The transcendent function. In R. F. C. Hull (Trans.), The collected works of C. G. Jung (Vol. 8, pp. 67-91). Princeton, NJ: Princeton University Press. (Original work published 1928)

Jung, C. G. (1970). The meaning of psychology for modern man. In R. F. C. Hull (Trans.), The collected works of C. G. Jung (Vol. 10, pp. 134-156). Princeton, NJ: Princeton University Press. (Original work published 1934)

Jung, C. G. (1970). The role of the unconscious. In R. F. C. Hull (Trans.), The collected works of C. G. Jung (Vol. 10, pp. 3-28). Princeton, NJ: Princeton University Press. (Original work published 1918)

Jung, C. G. (1970). The undiscovered self. In R. F. C. Hull (Trans.), The collected works of C. G. Jung (Vol. 10, pp. 245-305). Princeton, NJ: Princeton University Press. (Original work published 1957)

Jung, C. G. (1983). On the psychology and pathology of so-called occult phenomena. In R. F. C. Hull (Trans.), The collected works of C. G. Jung (Vol. 1, pp. 3-88). Princeton, NJ: Princeton University Press. (Original work published 1902)

Jung, C. G. (1989). Symbols and the interpretation of dreams. In R. F. C. Hull (Trans.), The collected works of C. G. Jung (Vol. 18, pp. 183-264). Princeton, NJ: Princeton University Press. (Original work published 1961)

Jung, C. G., \& Jaffé, A. (1989). Memories, dreams, reflections (Rev. ed). New York, NY: Vintage Books.

Kelso, C. (2015, February 10). Reuniting the apparent mind/body split. Retrieved February 17, 2019, from The Deepest Peace website: https://thedeepestpeace. com/2015/02/10/reuniting-the-apparent-mindbody-split/\#more-413

Maguire, R. (1997). "Proofs of God's existence:” Walker Percy, Jacques Maritain, and the problem of the symbol in the moviegoer. Logos: A Journal of Catholic Thought and Culture, 1(3), 69-79. doi: 10.1353/log.1997.0018

Meyer, M. (Ed.). (2007). The Nag Hammadi scriptures. San Francisco, CA: HarperSanFrancisco.

Pether, P. (1999). On foreign ground: Grand narratives, situated specificities, and the praxis of critical theory and law. Law and Critique, 10(3), 211-236. Retrieved from eoah: https://link.springer.com/article/10.1023/A:1008942114765.

Short, B. (2018). The depths of the Cartesian split: A hidden myth in modern psychology (Doctoral dissertation). Pacifica Graduate Institute. (10822143).

Spuybroek, L. (1999). The Cartesian split. ANY: Architecture New York, 24, 13-13. Retrieved from JSTOR: https://www.jstor.org/stable/i40087763.

von Franz, M.-L. (1972). Patterns of creativity mirrored in creation myths. Dallas, TX: Spring.

Baker, G. P., \& Morris, K. J. (2002). Descartes' dualism. London, UK: Routledge. Bolton, R. (1999). Dualism and the philosophy of the soul. Sacred Web, 4. Retrieved from: http://www.sacredweb.com/online_articles/sw4_bolton.html

Cottingham, J. (1998). Introduction. In J. Cottingham (Ed.), Descartes (pp. 1-27). Oxford, UK: Oxford University Press.

Cottingham, J., Stoothoff, R., \& Murdoch, D. (1985). Introduction. In The philosophical writings of Descartes (Vol. 1, pp. viii-x). Cambridge, UK: Cambridge University Press.

Descartes, R. (1985). The philosophical writings of Descartes (Vol. 1; J. Cottingham, R. Stoothoff, \& D. Murdoch, Trans.). Cambridge, UK: Cambridge University Press. 
Duffy, E. (2005). The stripping of the altars: Traditional religion in England; c. 1400 - c. 1580 (2nd ed.). New Haven, CT: Yale University Press.

Graffman, E. (2017). On Gregory Bateson's epistemology, his definition of mind, and its solution to the Cartesian dualism or mind-body problem. Rocznik Naukowy Kujawsko-Pomorskiej Szkoły Wyższej w Bydgoszczy. Transdyscyplinarne Studia o Kulturze (i) Edukacji, 12, 146-157.

Hodge, K. M. (2008). Descartes mistake: How afterlife beliefs challenge the assumption that humans are intuitive Cartesian dualists. Journal of Cognition and Culture, 8(3-4), 387-415.

Huxley, T. H. (1892). Essays upon some controverted questions. New York, NY: D. Appleton.

Johnson, G. (1997). Competing narratives: Retrieved February 26, 2017, from: http://gregscouch.homestead.com/files/henry8.html

Kirschbaum, L. (1977). Marlowe's Faustus: A reconsideration. In I. Ribner (Ed.), Doctor Faustus: Text and major criticism (pp. 87-106). Indianapolis, IN: Bobbs-Merrill.

Lovejoy, A. O. (1955). The revolt against dualism: An inquiry concerning the existence of ideas. Lasalle, IL: Open Court Publishing.

Owens, M. E. (2005). Stages of dismemberment: The fragmented body in late medieval and early modern drama. Newark, NJ: University of Delaware Press.

Richard, J. (2019, November 8). Gruesome ways people were executed in the time of Henry VIII. Retrieved November 8, 2019, from Ranker website: //www. ranker.com/list/gruesome-executions-time-of-henry-viii/jeffrichard

Selwood, D. (2015, November 5). Forget the Guy Fawkes propaganda-The English Reformation was a violent catastrophe. Retrieved from: http://www. telegraph.co.uk/news/religion/11976813/Forget-the-Guy-Fawkes-propagandathe-English-Reformation-was-a-violent-catastrophe.html

Sorell, T. (2005). Descartes reinvented. Cambridge, UK: Cambridge University Press.

Trevor-Roper, H. R. (1999). The crisis of the seventeenth century: Religion, the Reformation, and social change. Indianapolis, IN: Liberty Fund.

Weber, M. (1946). Science and Vocation. In H. Gerth \& C. W. Mills (Eds.), From Max Weber: Essays in sociology (pp. 129-156). New York, NY: Oxford University Press.

Wilson, M. D. (1993). Descartes. London, UK: Routledge, Taylor \& Francis.

Baker, G. P., \& Morris, K. J. (2002). Descartes' dualism. London, UK: Routledge.

Bordo, S. (1987). The flight to objectivity: Essays on Cartesianism and culture. Albany: State University of New York Press.

Bracken, H. M. (2002). Descartes. Oxford, UK: Oneworld.

Cole, J. R. (1992). The Olympian dreams and youthful rebellion of René Descartes. Urbana: University of Illinois Press.

Descartes, R. (1984). The philosophical writings of Descartes (Vol. 2; J. Cottingham, R. Stoothoff, \& D. Murdoch, Trans.). Cambridge, UK: Cambridge University Press.

Descartes, R. (1985). The philosophical writings of Descartes (Vol. 1; J. Cottingham, R. Stoothoff, \& D. Murdoch, Trans.). Cambridge, UK: Cambridge University Press.

Descartes, R. (1991). The philosophical writings of Descartes (Vol. 3; J. Cottingham, R. Stoothoff, D. Murdoch, \& A. Kenny, Trans.). Cambridge, UK: Cambridge University Press. 
Eshleman, M. (2007). The Cartesian unconscious. History of Philosophy Quarterly, 24(2), 169-187.

Frankfurt, H. G. (2008). Demons, dreamers, and madmen: The defense of reason in Descartes's meditations. Princeton, NJ: Princeton University Press.

Grof, S. (2000). Psychology of the future: Lessons from modern consciousness research. Albany: State University of New York Press.

Hutton, S. (2013). The Cambridge platonists. In E. N. Zalta (Ed.), The Stanford encyclopedia of philosophy. Retrieved from: https://plato.stanford.edu/archives/ win2013/entries/cambridge-platonists/

Jones, W. T. (1980). Somnio ergo sum: Descartes's three dreams. Philosophy and Literature, 4(2), 145-162.

Jung, C. G. (1969a). A review of the complex theory. In R. F. C. Hull (Trans.), The collected works of C. G. Jung (Vol. 8, pp. 92-104). Princeton, NJ: Princeton University Press. (Original work published 1934)

Jung, C. G. (1969b). Conscious, unconscious, and individuation. In R. F. C. Hull (Trans.), The collected works of C. G. Jung (Vol. 9.1, pp. 275-289). Princeton, NJ: Princeton University Press. (Original work published 1954)

Jung, C. G. (1970). A psychological view of conscience. In R. F. C. Hull (Trans.), The collected works of C. G. Jung (Vol. 10, pp. 437-455). Princeton, NJ: Princeton University Press. (Original work published 1958)

Kelso, C. (2015, February 10). Reuniting the apparent mind/body split. Retrieved February 17, 2019, from The Deepest Peace website: https://thedeepestpeace. com/2015/02/10/reuniting-the-apparent-mindbody-split/\#more-413

Lee, K. (2013). Reading Descartes otherwise: Blind, mad, dreamy, and bad. New York, NY: Fordham University Press.

Lokhorst, G. (2016). Descartes and the pineal gland. In E. N. Zalta (Ed.), The Stanford encyclopedia of philosophy. Retrieved from: http://plato.stanford.edu/ archives/sum2016/entries/pineal-gland/

Morris, K. (in press). The real distinction between mind and body. Forthcoming. In C. Lim \& J. Secada (Eds.), The Cartesian mind. London, UK: Routledge. https://www.amazon.co.uk/Cartesian-Mind-Routledge-Philosophical-Minds/ $\mathrm{dp} / 1138847429$

Morris, K. (2017). The hard problem of understanding Descartes on consciousness. In D. Jaquette (Ed.), The Bloomsbury companion to the philosophy of consciousness (pp. 11-26). London, UK: Bloomsbury.

Resnick, J. (2014, April 25). The effects of fluoride on consciousness and the will to act. Retrieved April 2, 2017, from The Conscious Reporter website: http://consciousreporter.com/conspiracy-against-consciousness/the-effectsof-fluoride-on-consciousness-and-the-will-to-act/

Sayin, H. Ü. (2014). Does the nervous system have an intrinsic archaic language? Entoptic images and phosphenes. NeuroQuantology, 12(3), 427-445. doi: 10.14704/nq.2014.12.3.756 